\title{
THE SPATIAL ANALYSES OF NATURAL RESOURCES USE IN RUSSIA FOR 1990-2017
}

\begin{abstract}
Trends in the development of natural resources use in Russia for 1991-2017 are presented. The role of industries based on mineral resources has increased over the post-Soviet years. The use of renewable natural resources is increasingly shrinking into compact areas near "central sites" and main transportation routes. The inventory of implemented investment projects was used as the basis for compiling a small-scale map to display the main features of industrial and transport development of the territory of post-Soviet Russia. The article states that topical changes in the natural-resource sphere do not match the criteria of sustainable development.
\end{abstract}

KEY WORDS: natural resource use, regional development, new trends, post-Soviet Russia

CITATION: Nikolay N. Klyuev (2019) The Spatial Analyses Of Natural Resources Use In Russia For 1990-2017. Geography, Environment, Sustainability, Vol.12, No 4, p. 203-211

DOI-10.24057/2071-9388-2018-65

\section{INTRODUCTION}

Natural resources, for which the territory of Russia has long been famous, are still providing Russia with survival and even development (however, very unstable development) in the conditions of the continuing crisis of recent decades. The contribution of the export of mineral resources alone to the country's hard currency proceeds 65-70\% (40-54\% in the Soviet Union in the 1980s) and at least half of the income of the federal budget (Klyuev 2015).

The high demand for Russian natural resources in the global market preconditions Russia's place as a resourceproviding zone on the planet; the strategic significance of the natural resource 1 Natural resource complex is a set of industries that extract and primary processing of natural resources: extractive industry, agriculture, forestry, water industry, fishery, etc. complex ${ }^{1}$ in the country's economy; and the priority of the earth sciences, including geography, in the Russian scientific sphere.

Development trends of the Russian natural resource complex as a whole in the postSoviet period were considered in domestic and foreign literature (Doroshenko et al. 2014; Bradshaw and Connolly 2016; et al.). However, we are not aware of studies of the spatial patterns of these trends.

The purpose of the article is to determine the post-Soviet trends in the development of the Russian natural resource complex and their compliance with the criteria for sustainable development. For the first time, an attempt is made to map the post-Soviet industrial and transport development of Russian territory. 


\section{MATERIALS AND METHODS}

The materials for the study were official statistics (Russian Statistical Yearbook 2017; 1994). The mapping is based on materials from business journalism gathered by this author, and regional, sectoral and corporate Internet websites as well as data reported by separate researchers (Litvinenko 2014; Makhrova et al. 2008; Savelyeva 2012). A total of 1040 projects were taken into account: 981 point objects (industrial enterprises and their facilities) located in 600 settlements as well as in uninhabited areas, and 59 objects of linear transport infrastructure (pipelines, railroads, and power lines) ${ }^{2}$. Because of the specific nature of information, the map (Fig. 1) displays only a representative sample of the largest investment projects implemented to date.
The main research method is integrated small-scale thematic mapping.

\section{RESULTS AND DISCUSSION}

After a significant drop in the 1990s, the production of non-renewable mineral resources in Russia practically reached the Soviet level by the 2010s and even exceeded it in some positions (Table 1). An exception is the extraction of nonmetallic building materials, which has shrunk by a third. This was caused by a drastic reduction in industrial, transport, and residential construction, since the industry of construction materials works for the domestic market. On the contrary, the extraction of fuel and energy resources, ferrous and nonferrous metal ores, and chemical raw materials are largely export oriented, which predetermines Russia's status as a warehouse of the world's mineral resources.

Table 1. Dynamics of the extraction of mineral resources and production based on renewable resources in Russia over 1990-2017 (1990 = 100\%)

\begin{tabular}{|c|c|c|c|}
\hline Product / Year & 1990 & 2000 & 2017 \\
\hline Coal & 100 & 65 & 104 \\
\hline Oil & 100 & 63 & 106 \\
\hline Natural gas & 100 & 91 & 108 \\
\hline Iron ore & 100 & 81 & 89 \\
\hline Nonmetallic building materials & 100 & 27 & 68 \\
\hline Fertilizers & 100 & 76 & 141 \\
\hline Peat & 100 & 39 & 50 \\
\hline Commercial wood & 100 & 31 & 53 \\
\hline Fish & 100 & 47 & 58 \\
\hline Grains & 100 & 62 & 107 \\
\hline Cattle and poultry & 100 & 49 & 98 \\
\hline Milk & 100 & 62 & 57 \\
\hline Eggs & 100 & 68 & 89 \\
\hline Wool & 100 & 24 & 25 \\
\hline
\end{tabular}

2 We made the first attempt at the inventory and mapping of the new construction projects in (Klyuev 2018): we compiled the map displaying about 950 projects.

Source: Russian Statistical Yearbook 2017; 1994.

Note. Five-year averages for agricultural products: 1990 for 1986-1990; 2000 for 1996-2000; and 2017 for 2013-2017. 
The export orientation of the mining industry significantly increased during the years of restoration of capitalism in Russia (Table 2). Russia is the world's largest exporter of natural gas, while the gasification of, for example, Sakhalin region (a gas-producing region) is $14.2 \%$ (2017); in rural districts this index is much lower. Russia exports most (up to 90\%) of the aluminum, copper, nickel, and zinc it produces as the domestic consumption of the non-ferrous metallurgy products, which refines the economy and makes its structure more progressive, has dropped drastically. The Soviet Union consumed over $10 \%$ of the world's aluminum; contemporary Russia consumes 10 times less; copper consumption has decreased by 8 times, and nickel consumption has decreased by 12 times (Kashin 2009).
Against the backdrop of the increasing exploitation of the subsurface, renewable resource-based industries have drastically reduced the production over the postSoviet period. It is noteworthy that sustainable development implies the gradual replacement of non-renewable mineral resources with renewable ones. It is clear that this problem cannot be solved overnight. However, it is hard to rely on solving it if we move in the opposite direction.

A distinctive geographical feature of the Russian natural-resource complex has been the almost full spatial incongruity of human and resource distribution (an exception is the soil-climatic resources). Siberia and the Far East, inhabited by $20 \%$ of the population, have $70 \%$ of the

Table 2. Extraction and export of oil, gas, coal, and iron ore in Russia

\begin{tabular}{|c|c|c|c|c|c|}
\hline Mineral resources / Year & 1993 & 2000 & 2005 & 2011 & 2017 \\
\hline \multicolumn{6}{|c|}{ Oil, million tons } \\
\hline Extraction & 354 & 324 & 470 & 512 & 546 \\
\hline Export & 80 & 145 & 253 & 244 & 253 \\
\hline Export share on extraction, \% & 22.6 & 44.7 & 53.8 & 47.7 & 46.3 \\
\hline \multicolumn{6}{|c|}{ Natural gas, billion cubic meters } \\
\hline Extraction & 618 & 584 & 641 & 671 & 691 \\
\hline Export & 96 & 194 & 207 & 187 & 210 \\
\hline Export share on extraction, \% & 15.5 & 33.2 & 32.3 & 27.9 & 30.4 \\
\hline \multicolumn{6}{|c|}{ Coal, million tons } \\
\hline Extraction & 306 & 258 & 299 & 335 & 410 \\
\hline Export & 20 & 44 & 80 & 111 & 181 \\
\hline Export share on extraction, \% & 6.5 & 17.1 & 26.8 & 33.1 & 44.1 \\
\hline \multicolumn{6}{|c|}{ Iron ore, million tons } \\
\hline Extraction & 76 & 87 & 95 & 104 & 95 \\
\hline Export & 10 & 19 & 18 & 28 & 21 \\
\hline Export share on extraction, $\%$ & 13.2 & 21.8 & 18.9 & 26.9 & 22.1 \\
\hline
\end{tabular}

Source: Russian Statistical Yearbook 2017; 1994. 
natural-resource potential, excluding agricultural resources. This circumstance predetermines the key problems of developing the country's natural resources: expensive extraction in the conditions of "ice isotherms"; the absence of roads, infrastructure, and labor; and the high price of the transportation of extracted raw materials to consumers. All these problems only worsen with time.

The agrarian profile of the regions has changed, shifting toward crop production. In the 1980s, it prevailed only in several southwestern regions, and now it already dominates most of the country's territory, from the dry steppes to the tundra. The relation between crop production and livestock production is of high environmental, in addition to economic, importance. It predetermines the type and intensity of agrarian loads on nature and the proportions between farmland types (plow land, hay land, and pastureland) and, thus, the face of contemporary rural landscapes.

The characteristic features of the current period are the preferred shrinkage of the Russian resource space, the concentration of natural resource use in "central parts," and the economic desolation of the periphery. This is indicated by the distribution of industrial investments, which are, in fact, future anthropogenic loads, by the country's regions. There is a concentration of the use of natural resources in relatively well (by Russian standards) developed territories, where the pressure on nature has previously been high. Beyond the Urals, only the Khanty-Mansi and Yamalo-Nenets autonomous districts in Tyumen' region are noticeably distinguished by the level of investment concentration.

The inventory of implemented investment projects was used as the basis for compiling a small-scale map to display the main features of industrial and transport development of the territory of post-Soviet Russia (Fig 1). An exceptional spatial differentiation of industrial construction is revealed, expressed primarily in its superconcentration in the Moscow region, as well as in the northwest (St. Petersburg and Leningrad region). The northern and eastern regions of the country are characterized by focal industrial development and the dominance of mining enterprises. In Asiatic Russia large-scale industrial construction is allocated to Kuzbas, Khanty-Mansi, and Yamalo-Nenets autonomous districts, but the "density" of development is small (Fig 2). The resulting map reveals new foci and areas of change in the natural environment and its large-scale transformation. The analysis of the structure of new industrial construction did not reveal any signs of its greening. 2/3 of new facilities are related to basic, environmentally "aggressive" industries.

The key cause and, simultaneously, indicator of the desolation of northern and eastern regions of the country is the reduction of their population. Between 1991 and 2017, the reduction amounted to $35 \%$ in Murmansk region, $61 \%$ in Magadan region, and almost 68\% in Chukotka autonomous district.

The rate of drawdown in forest harvesting in the main forestry regions is higher than in other regions of the country. Remote wood cutting areas are abandoned, and forest extraction is concentrated near thoroughfares. In forest deficient regions, where the forests are heavily disturbed, increased felling is observed. In mountainous regions, especially in the North Caucasus, mid-mountain and lowmountain forests and shrubs are felled intensively for firewood, thus increasing the areas of mudflow sites.

At the same time, the 2000s witnessed patchy involvement of export-oriented resources in newly developed regions, mainly in the north and east of the country. Among large subsurface development projects in post-Soviet Russia, we should note oil and gas extraction at the Vankor oil and gas, Yurobcheno-Tokhomsk oil and gas condensate (Krasnoyarsk krai), and Talakan oil (Yakutia); fields on the 
shelves of the Okhotsk, Caspian, Baltic, Black, and Pechora seas; the advance of gas extraction in the Yamalo-Nenets autonomous district to the north; the preparation of the development of Timan bauxites; etc.

The focal development of resources is becoming more deconcentrated. Now there are no giant deposits like Samotlor, Urengoy, and Medvezh'e. In the early 1970s, the average size of reserves at newly discovered oil deposits in Western Siberia was 77 million tons (30 million tons in the Russian Soviet Federative Socialist Republic); now it is 1 million tons. What we see now are the signs of a late stage in the life cycle in the country's main "hard currency shop"-the Western Siberian oil and gas province. An increasing number of infield and interfield pipelines is needed for each unit of resources extracted. This increases the environmental risks, since such pipelines spill at least 1\% of the oil produced.

Against the background of the significant reduction in transportation, which reduced the effects of hazardous transport on roadside landscapes on territories between populated localities, a pipeline-port boom is observed, causing the transfer of transport-environmental threats to offshore zones and their approach to the Russian borders. Here we may single out the Blue Stream, Nord Stream, and Yamal-Europe gas pipelines; the Turkish Stream and Power of Siberia gas pipeline projects; the Eastern SiberiaPacific Ocean oil pipeline; the Baltic pipeline system (Kirishi-Primorsk); the Primorsk oil transshipment terminal; the Vitino (Murmansk region) and Privodino (Arkhangelsk region) oil terminals; etc. The export-oriented raw-stock model of the Russian economy is secured in new investments.

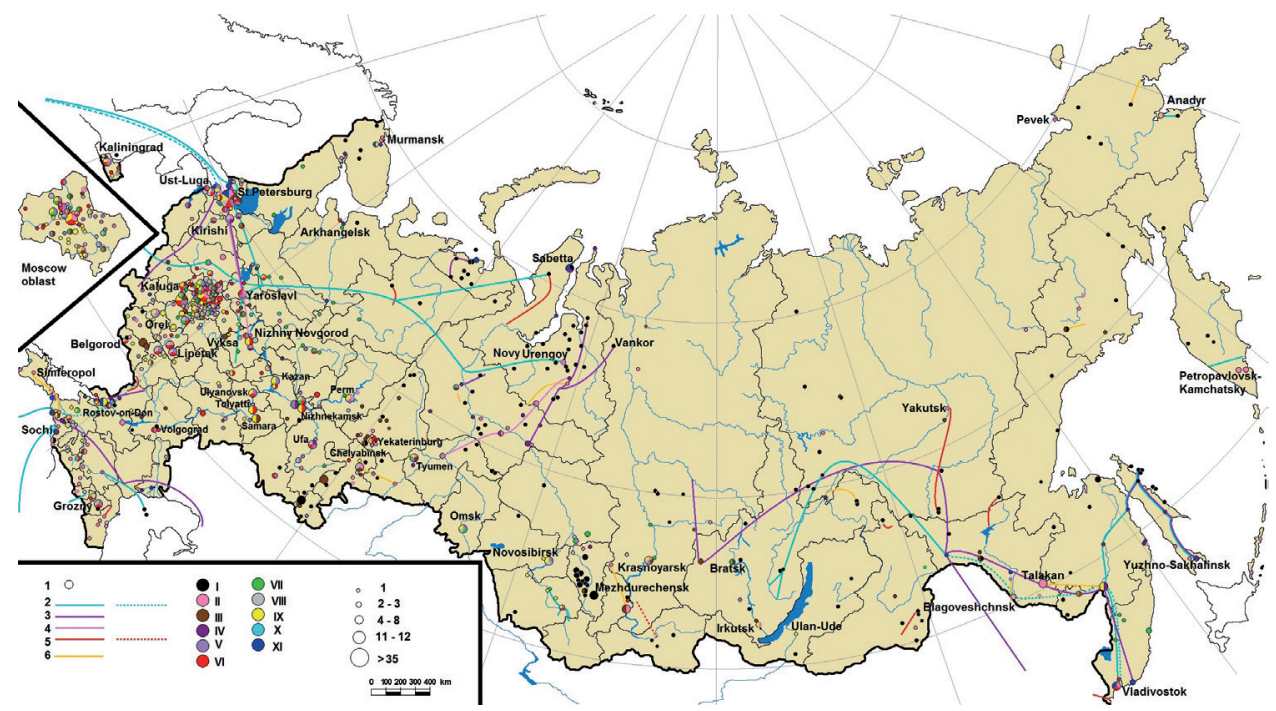

Fig. 1. Industrial and transport projects on the territory of Russia in the post-Soviet period

Projects: 1 - industrial enterprises, 2 - gas pipelines (the project under construction is shown as a dashed line), 3 - oil pipelines, 4 - petroleum product pipelines, 5 - railroad (the railroad under construction is shown as a dashed line), 6 - power transmission line.

Sectors of the economy: I - extractive industry, II - electricity, III - metallurgy, IV - oil refining industry, $\mathrm{V}$ - chemical and petrochemical industry, $\mathrm{VI}$ - mechanical engineering and metalworking, $\mathrm{VII}$ - timber, forest product and pulp and paper industry, VIII - building materials industry, IX - food industry, $X$ - light industry, $X I$ - ports and terminals.

The size of the circle indicates the number of projects.

Cartographer - A.N. Vasiltsova. 


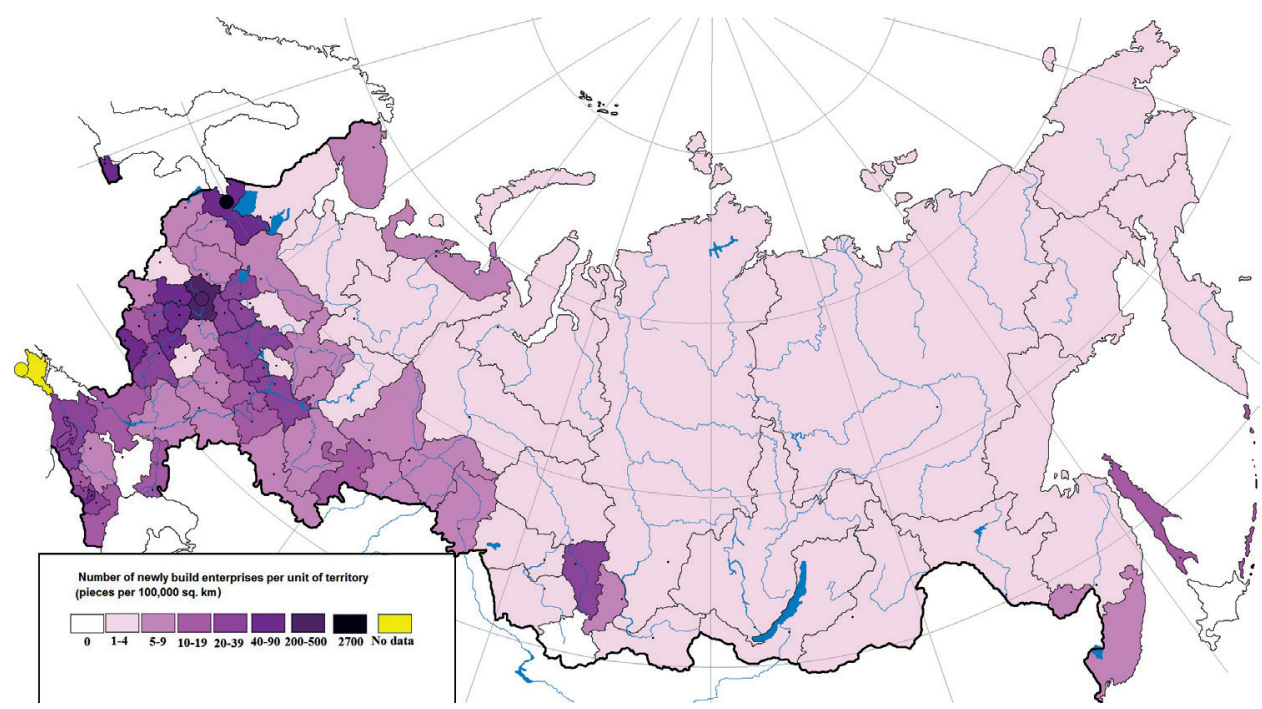

Fig. 2. Industrial construction in Russia in the post-Soviet period

"The whole history of Russia is related to the development of vast land .... This is its function and, if you like, mission" (Sysoeva 2007). Therefore, the development of new natural resources follows the main path of the country's development, but with an important reservation. The key innovation of the contemporary world is the environmental imperative. The unique diversity of Russian landscapes should be developed carefully, with account for the spatiotemporal characteristics of their resistance to technogenesis. Development is not just the expansion of mining facilities, which leave behind an anthropogenic desert. Environmental development implies the arrangement of a territory, the organization of tourist and recreation zones on it, territories of different security levels, organic agriculture, progressive means of transportation and communications, traditional crafts of small nations, etc.

Thus far, unfortunately, the principles of sustainable development have not become a regular fixture in domestic natural resources use. At first sight, new mining facilities should show a high degree of environmental friendliness. However, this is not always the case. New oil extraction fields in the Khanty-Mansi autonomous district are not included into the network of operations that utilize the associated petroleum gas. Newly commissioned oil fields have a very low degree of gas utilization. Only at old and well-developed fields it can reach 60-90\%. Russian oil and gas deposits on the Arctic shelf should be viewed as a resource for future generations. Their frontal development in the next 10-20 years is unwarranted for several reasons, including those related to climate transformation. Changes are manifested, in particular, in the acceleration of extremely hazardous phenomena, fraught with environmental emergencies. Severe but stable natural conditions are very costly; however, they do not involve readily predictable consequences. At the same time, the "efficient presence" on a territory is needed for geopolitical reasonsinfrastructural development of navigation in Arctic regions, the intensification of the information stage of their development (exploration, monitoring, etc.), and colossal capital investments, required for new shelf projects, must be channeled to improve the recovery of oil and gas resources at already developed deposits.

Unfavorable features of the geographical position of our country hinder its frontal inclusion into international labor division. A scientifically justified territorial policy can and should strengthen the merits of Russia's location and smooth out its 
drawbacks. This can be done by organizing railroad and marine super-thoroughfares "from the English to the Japanese" and a central link of a single integral infrastructure of Eurasia on Russian land and in Russian waters.

The years of perestroika, crises, and reforms have escalated the problem of information support for the country's natural resource complex. The development of mineral riches has still been mainly based on reserves explored by Soviet geologists, which betokens an imminent resource crisis. The reduction of things to order in the "book accounting" of natural values is an important task of national administration, and geographers can and should contribute to its solution. Knowledge obtained by the earth sciences is of strategic importance for the country's sustainable development. It is necessary to intensify the scientific investigation of Russian territory - the most environmentally friendly and geopolitically essential form of its development.

\section{CONCLUSION}

In the post-Soviet years, the Russian economy has seen the strengthening of the role of the natural resource complex, and the importance of industries based on mineral resources has increased in its structure. In addition, gaps between the extraction and processing of mineral resources, as well as between extraction and internal consumption, are increasing. The export orientation of the natural resource sphere is growing. This dynamics does not correspond to the objectives of the country's innovative, informational, and environmentally oriented development.

The export-oriented mineral resource complex is experiencing an expansion of the resource space: the focal involvement of new resources of Eastern Siberia, the Far East, the North, and the shelf regions into exploitation. As opposed to this, the use of renewable (biological, forest, soil, agroclimatic, aquatic) resources, as well as non-ore construction materials consumed inside the country, is concentrated in compact areas near central parts and main thoroughfares and is oriented at the use of the "best lands". Topical changes in the natural resource sphere do not match the criteria of sustainable development.

It is important to undertake efforts to reanimate industries that are based on renewable resources and that have suffered severely during the crisis and reforms: agriculture, forestry, water industry, fishery, etc. In addition to economic and environmental effects, their restoration and development will also yield a geopolitical result. These industries are crucial in "rebuilding" the country's territory.

The small-scale map, compiled on the basis of a selective inventory of the investment projects thus far implemented reflects the main features of industrial and transport development of post-Soviet Russia. The study revealed an exceptionally high territorial differentiation of industrial construction which implies primarily its overconcentration in the Moscow region as well as in the North-West (the city of St. Petersburg and Leingrad region). The northern and eastern areas of the country are distinguished by focal industrial development, and by a predominance of extractive enterprises. No shift of productive forces to the east, which is necessary for ensuring geopolitical stability of the country and leveling off the industrial load on the environment over the territory, has been observed at all.

The analysis of the structure of new industrial construction did not reveal any signs of its "greening". Two thirds of the new projects refer to the basic, environmentally "aggressive" sectors.

The newly constructed transport infrastructure facilities (pipelines, railroads, ports, and terminals) are largely exportoriented rather than enhancing the connectivity of its territory.

The compiled map of industrial and transport construction reveals new 
foci and areas of changes in the natural environment and its largescale transformation. The growing concentration of economic life in sparse areas of economic activity is the main vector of Russia's spatial development. Having developed in the conditions of market chaos, it is of poor quality from both the environmental and geopolitical positions

\section{ACKNOWLEDGEMENTS}

The study was performed within the budgetary topic of the Institute of Geography, Russian Academy of Sciences, 0148-2019-0008 "Problems and Prospects of Territorial Development of Russia in Conditions of Its Unevenness and Global Instability" (analysis) and under Program no. 53 of the Presidium of the Russian Academy of Sciences, "Spatial Restructuring of Russia with Regard to Geopolitical, Socioeconomic, and Environmental Challenges" (collection of materials and cartography).

\section{REFERENCES}

Doroshenko S.V., Shelomentsev A.G., Sirotkina N.V., and Khusainov B.D. (2014). Paradoxes of the "natural resource curse" regional development in the post-Soviet space. Regional Economy, 4, pp. 81-93. DOI: 10.17059/2014-4-6.

Bradshaw M. and Connolly R. (2016). Russia's Natural Resources in the World Economy: history, review and reassessment. Eurasian Geography and Economics, (57), pp. 1-27. DOI: 10.1080/15387216.2016.1254055.

Kashin V.I. (2009). Natural Resources as Part of Russia's National Riches. The Use and Protection of Natural Resources in Russia, (5), pp. 3-7 (in Russian)

Klyuev N. N. (2018). Industrial and Transport Development of the Territory of Russia in the Post-Soviet Period. Geography and Natural Resources, 39(1), pp. 1-9. DOl: 10.1134/ S1875372818010018

Klyuev N.N. (2015). Russia's Natural-Resource Sphere and Trends in Its Development. Herald of the Russian Academy of Sciences, 85(4), pp. 303-315. DOI: 10.1134/S1019331615030016

Litvinenko T.V. (2014). Post-Soviet Transformation of Resource Management and Its SocialEnvironmental Consequences in Eastern Regions of Russia. In: I.N. Volkova and N.N. Klyuev, ed., Environmental Management in Territorial Development of Modern Russia, Moscow: Media-Press, pp. 251-283. (in Russian with English summary)

Makhrova A.G., Nefedova T.G., and Treivish A.I. (2008). Moscow Oblast Today and Tomorrow: Tendencies and Prospects of Spatial Development. Moscow: Novyi Khronograf (in Russian)

Russian Statistical Yearbook. 2017. [online] Available at: http://www.gks.ru/bgd/regl/ b17_13/Main.htm [Accessed 07 Nov. 2018].

Russian Statistical Yearbook. 1994. Moscow: Goskomstat (in Russian)

Savelyeva I.L. (2012). Eastern Siberia: The Formation Potential of the TPC of Polyresource Nature Management. In: Russia and Its Regions: Integration Potential, Risks and Avenues for the Transition to Sustainable Development. Moscow: KMK, pp. 380-399 (in Russian with English summary) 
Sysoeva N.M. (2007). The Processes of Economic Development of Siberia, and the Current Problems of Territorial Development. Geography and Natural Resources, (3), pp. 37-41. (in Russian with English summary)

Received on November $11^{\text {th }}, 2018$ Accepted on November $07^{\text {th }}, 2019$ 